DOI: https://doi.org/10.15407/techned2018.05 $=\underline{007}$

\title{
MAGNETIC FIELD CALCULATION OF BRUSHLESS DIRECT CURRENT MOTOR WITH SMOOTH STATOR BY SECONDARY SOURCES METHOD
}

Journal

Publisher

ISSN

Issue

Pages
Tekhnichna elektrodynamika

Institute of Electrodynamics National Academy of Science of Ukraine 1607-7970 (print), 2218-1903 (online)

No 5, 2018 (September/October)

$7-10$

\section{Authors}

\section{A.V. Zhyltsov ${ }^{\star}$, V.V. Lyktei ${ }^{*}$}

National University of Life and Environmental Sciences of Ukraine, str. Geroiv Oborony, 12,

Kyiv, 03041, Ukraine,

e-mail: azhilt@gmail.com

* ORCID ID : http://orcid.org/0000-0002-1688-7879

** ORCID ID : http://orcid.org/0000-0002-7412-5143

\section{Abstract}

A mathematical model of a brushless direct current motor (BLCM) with high-corrosion permanent magnets is developed. It is based on the secondary sources method, and allowed the problem of calculating the magnetic permeability distribution in the engine ferromagnetic elements to reduce to solving a system of integral equations of the simple layer density and the volume density magnetic charges. An iterative method of finding the magnetic permeability is proposed taking into account the nonlinear dependence of the magnetic permeability. Referenc es 10 , figures 3 . 
Key words: ac converter-fed motor, magnetic permeability, nonlinearity, secondary sources method.

Received: 06.03 .2018

Accepted: 02.05 .2018

Published: 16.08 .2018

\section{References}

1. Arakelyan A.K., Afanasyev A.A. Gate electric machines in the systems of adjustable electric drives. Moskva: Vysshaia Shkola, 2006. Vol.1.545 p. (Rus)

2. Arakelyan A.K., Afanasyev A.A. Gate electric machines in the systems of adjustable electric drives. Moskva: Vysshaia Shkola, 2006. Vol. 2. 517 p. (Rus)

3. Lebedev N.I., Gandshu V.M., Yavdoshak Ya.I. Valve electrical machines. SPb.: Nauka, 1996. 352 p. (Rus)

4. Matyuk V.F., Osipov A.A. Mathematical models of magnetization curve and magnetic hysteresis loops. Part I. Analysis of models. Non-destructive testing and diagnostics. 2011. No 2. Pp. 3 - 35. (Rus)

5. Matyuschenko A.V. Field Mathematical models of valve motors with permanent magnets and their comparative analysis. Electrical engineering \& Electromechanics. 2015. No 1. Pp. $25-28$. (Rus)

6. Ovchinnikov I.E., Anakhin D.S. High-speed valve motor with permanent magnets. Design principle. Scientific and Technical Herald of Information Technologies, Mechanics and Optics. 2005. Issue 20. Pp. $103-110$. (Rus)

7. Risovany S.V., Finkelstein V.B. Design of valve jet engines: monograph. Kharkov: NUUE, 2014. 245 p. (Rus)

8. Zhyltsov A.V., Lyktei V.V. Calculation of the magnetic field in a valve electric motor with closed grooves based on nonlinear magnetic characteristic. Electromechanical and energy 
saving systems. Quarterly Scientific and Production Magazine . 2014. Vyp. 4. Pp. 59 - 70. (Ukr)

9. Zhyltsov A.V., Lyktei V.V. Modeling of the magnetic field in a valve electric motor with closed grooves based on a nonlinear magnetic characteristic. Scientific Bulletin of the National University of Life and Environmental Sciences of Ukraine. Series: Engineering and Power Engineering of Agroindustrial Complex

. 2016. Vol. 256. Pp. 178 - 186. (Ukr)

10. Zhyltsov A.V., Lyktei V.V. The boundary value problem for a three-dimensional magnetic field with allowance for a nonlinear magnetic medium. Problems of energy saving in electrical engineering systems. Science, education and practice. Scientific publication

. 2014. Vol. 1(2). Pp. $124-126$. (Ukr)

$\underline{\text { PDF }}$ 